\title{
New Pharmacological Targets for Asthma Drug Development
}

Carla Máximo Prado', Renato Fraga Righetti ${ }^{2}$, Patricia Angeli da Silva Pigati ${ }^{2}$, Samantha Souza Possa ${ }^{2}$, Anelize Sartori Alves dos Santos ${ }^{2}$ Nathalia Montouro Pinheiro ${ }^{2}$, Alessandra Choqueta de Toledo², Edna Aparecida Leick ${ }^{2}$, Mílton de Arruda Martins ${ }^{2}$ and lolanda de Fátima Lopes Calvo Tibério ${ }^{2 *}$

${ }^{1}$ Department of Biological Science, Universidade Federal de São Paulo, Brazil.

${ }^{2}$ Department of Medicine, School of Medicine, University of São Paulo, Brazil

\begin{abstract}
Asthma is an inflammatory disorder characterized by airway hyperresponsiveness, followed by inflammation, remodeling and oxidative stress in the respiratory system and lung tissue. While glucocorticosteroids remain the gold-standard of asthma therapy, they have limitations because of their potentially severe adverse effects and the presence of corticosteroid resistance in some patients. In the present review we will focus in four main groups of experimental pharmacological approaches for future asthma and hyperresponsiveness treatment: proteinase inhibitors and flavonoids, arginase and iNOS inhibition, Rho-kinase inhibitors, cholinergic anti-inflammatory system and nicotinic receptors.
\end{abstract}

\section{Introduction}

Asthma, a common lung disease affecting millions of people worldwide, is associated with a partially or completely reversible narrowing of the airways, chronic allergic inflammation and hyperresponsiveness. Asthmatics are sensitive to a variety of stimuli, which may include viral illnesses (e.g., the common cold), allergens, exercise, medicines and environmental conditions. The majority of asthmatic patients can usually be treated successfully. The usual goals of asthma treatment are prevent chronic and troublesome symptoms, normalize pulmonary function, maintain normal activity levels, prevent exacerbations, improve the health-related quality of life, and provide optimal pharmacotherapy with minimal or no adverse effects. The treatment of asthma requires a multidisciplinary approach that includes to patient education needs, the avoidance of irritant and allergic triggers and the design of an optimal medication regimen. The treatment of certain comorbid conditions such as allergic rhinitis, symptomatic gastroesophageal reflux disease (GERD), vocal cord dysfunction, obstructive sleep apnea, obesity, anxiety and depression, may contribute to the improvement of asthma management. The cessation of smoking is also imperative $[1,2]$.

In addition, it is worthwhile to monitor lung health using a diary as well as by performing measurements of the rate at which patients can exhale, which is dependent on the degree of airway narrowing. Hence, a peak flow meter, an inexpensive and easily managed instrument, can be used to monitor lung function and the response to treatment, to assess the severity of asthma attacks, and to guide decisions regarding treatment [2].

The primary medications for asthma treatment vary according to age and the severity of the clinical and functional evaluation. These factors must be reviewed and adjusted for the required level of symptom control. The preferred way of taking medication for asthma is by inhalation, which allows the medication to take effect rapidly with maximal strength and minimal side effects.

The short-acting bronchodilators (usually beta-2 agonists) are the main drugs used for the rapid control of asthma symptoms. The great majority of patients with the mildest form of asthma or the intermittent type will require these drugs only occasionally. These drugs must be used as needed for the relief of asthma symptoms, or preventively prior to an activity that is known to provoke those symptoms. Asthmatics with persistent asthma need to take medications on a daily basis and which are called "long-term controllers". In this regard, inhaled corticosteroids, the gold standard for asthma treatment, act to decrease chronic pulmonary allergic inflammation. The most common side effects are oral candidiasis, cataracts, glaucoma, easy bruising of the skin, and osteoporosis. The risk of these complications is far less with inhaled glucocorticoids compared with oral glucocorticoids. The addition of a long-acting inhaled bronchodilator (salmeterol, formoterol) is often necessary in combination with an inhaled steroid, for adults with persistent asthma [2].

Leukotriene modifiers, such as montelukast, zafirlukast or zileuton are an alternative to inhaled glucocorticoids. They have a bronchodilator effect, decreasing inflammation and mucus secretion and production [3]. However, it is important to emphasize that compared with inhaled glucocorticoids; leukotriene modifiers are generally less effective in controlling asthma. It is noteworthy that leukotriene modifiers can be used to prevent exercise-induced asthma. In patients with uncontrolled asthma taking these previously discussed medications, an oral steroid may be added to the treatment regimen, which augments the possibility of side effects [2].

However, a group of patients with severe asthma requires high dose inhaled glucocorticoid (GC) or continuous or near continuous oral GC treatment to maintain their asthma control. For these patients, the treatment is based on oral glucocorticoids, high doses of inhaled GC, the addition of a third controller agent, such as an anti-leukotriene agent or theophylline or even anti-IgE therapy in atopic allergic patients $[4,5]$. The long acting bronchodilators (LABA) should be added and tiotropium should be reserved for those patients who have

*Corresponding author: Iolanda de Fátima Lopes Calvo Tibério, Department of Medicine, School of Medicine, University of São Paulo, Av. Dr. Arnaldo, 455 - Sala 1216, 01246-903 - São Paulo, SP, Brazil, Tel: +55 11 3085-0992; Fax: +55 113061 7317; E-mail: iocalvo@uol.com.br

Received January 29, 2013; Accepted March 20, 2014; Published March 25 2014

Citation: Prado CM, Righetti RF, da Silva Pigati PA, Possa SS, dos Santos ASA et al. (2014) New Pharmacological Targets for Asthma Drug Development. Allergy Ther 5: 170. doi:10.4172/2155-6121.1000170

Copyright: ( 2014 Prado CM, et al. This is an open-access article distributed unde the terms of the Creative Commons Attribution License, which permits unrestricted use, distribution, and reproduction in any medium, provided the original author and source are credited. 
ongoing asthma symptoms and airflow limitation despite combination therapy with inhaled glucocorticoids/LABA [6]. However, persistent symptoms may be present despite such high dose combination therapy. This may be due to the presence of distal airway and alveolar septa inflammation, extracellular matrix remodeling as well as altered glucocorticoid receptor expression $[7,8]$.

Various pharmacologic and non-pharmacologic agents have been used in an attempt to improve asthma control and ameliorate the many adverse effects of chronic oral GC therapy in patients with severe asthma. Immunomodulatory therapies such as methotrexate and cyclosporine specially have side effects that are substantial and likely to outweigh any potential benefits. Other immunomodulatory drugs, such as azathioprine, cyclophosphamide, and mycophenolic acid have not undergone treatment trials for severe asthma [2].

Monoclonal antibodies against interleukin 5 (anti-IL-5) have been studied for use in asthma because of the potent effect of IL- 5 on eosinophil recruitment to the airways. Treatment with the anti-IL-5 monoclonal antibodies, mepolizumab and reslizumab, may be beneficial in a small subgroup of patients with persistent airways eosinophilia that is resistant to glucocorticoid therapy. This class of medication is not approved by the US Food and Drug Administration nor is it readily available. The anti-IL-4 alpha subunit antibody, dupilumab, is a fully human monoclonal antibody that binds to the alpha subunit of the IL-4 receptor and inhibits the downstream signaling induced by both IL-4 and IL-13. Early evidence suggests that it may be useful for patients with moderate-to-severe asthma with persistent peripheral blood eosinophilia. The inhibitors of tumor necrosis factor (TNF)alpha have been studied in the treatment of asthma. The largest trial did not achieve the primary endpoints (reduction in exacerbations and improvement in FEV1), and substantial side effects were noted [9]. Macrolide antibiotics have both antimicrobial and anti-inflammatory actions. They should be prescribed for those patients who report the onset of asthma after a respiratory illness suggestive of these organisms [2].

Although glucocorticoids (GCs) have potent anti-inflammatory properties it is now clear that asthma is a syndrome with many distinct and overlapping phenotypes. The patients with GC-resistant asthma do not benefit from GC treatment and present a major healthcare problem. They account for a large percentage of the overall costs of asthma worldwide but also provide unique insights into the mechanisms of GC action. For clinical purposes, GC-resistant asthma is defined by an FEV1 of less than 75 percent of predicted and a failure to improve by 15 percent after an adequate dose and duration of glucocorticoid therapy. Glucocorticoid resistance is most likely produced by a number of heterogeneous effects such as defects in most aspects of intracellular GR actions, the binding of GCs to GR and the nuclear translocation of the GC-GR complex. However, it is likely that the major mechanisms for GC resistance occur distally to the nuclear translocation step, such as in the splicing of RNA, cytokine expression, binding to the GC response elements on DNA, and interactions of the GC-GR complex with other nucleoproteins [10].

The management of patients with GC-resistant asthma presents unique challenges because of a lack of effective and well-tolerated alternatives to GCs. Treatment strategies include the avoidance of asthma triggers, using higher doses and a longer duration of systemic glucocorticoids, and the use of non-glucocorticoid agents. Current research is focused on identifying new immunomodulatory agents and non-pharmacologic therapies [11].
In the present review we will focus on four main groups of experimental pharmacological approaches for future asthma and hyperresponsiveness treatment: 1. Proteinase inhibitors and flavonoids; 2 . Arginase and iNOS inhibition; 3 . Rho-kinase inhibitors and 4 . Cholinergic anti-inflammatory systems and nicotinic receptors.

\section{Proteinase Inhibitors and Flavonoids}

Because proteinases are no longer considered only as enzyme and/or involved in protein degradation, they have become important signaling molecules involved in many vital biological processes. Considering these facts, proteinase inhibitors are being intensively investigated, mainly for their involvement in cell-signaling $[12,13]$

Proteases are enzymes that catalyze the breakdown of proteins by hydrolysis of their peptide bonds. Using bioinformatic analysis of the mouse and human genomes, at least $500-600$ proteases $(\sim 2 \%$ of the genomes) have been identified, many of which are orthologous $[14,15]$.

Proteases can specifically cleave protein substrates, and their primary role has long been considered to be for protein degradation related to food digestion and intracellular protein turnover [16]. Accordingly, many proteases are a major focus of attention for the pharmaceutical industry as potential drug targets or as diagnostic and prognostic biomarkers [12].

Although the involvement of proteinases in the pathophysiology of emphysema is established [17], there is also evidence for their relevance to asthma [18]. Furthermore, many aeroallergens associated with asthma, such as house dust mite allergens and various fungal allergens, are themselves proteinases $[19,20]$.

The proteinase inhibitors are of vegetable or animal origin and block a hydrolytic enzyme for a given substrate. Thus, inhibitors of a proteinaceous nature are capable of producing complexes with enzyme, thereby inhibiting their catalytic activity and acting on a specific group of enzymes. There are inhibitors described for cistein proteinases, serine proteinases, metalloproteinases, and aspartic proteinases, but they can also be multifunctional because they have the ability to inhibit enzymes of different classes simultaneously [21].

Serine proteinase inhibitors (SPIs) are found widely in all multicellular organisms and take part in controlling various proteinasemediated biological processes, such as digestion, the complement system, blood coagulation, melanization, apoptosis, phagocytosis, cellular remodeling and reproductive processes [22].

Tryptase, a serine protease, has also been shown to contribute to the pathophysiologic responses associated with asthma [23]. Moreover, inhibitors of tryptase have been effective in reducing or abolishing early and late-phase allergen-induced bronchoconstriction in animal models [24]. In addition, inhibitors of tryptase have been shown to prevent bronchoconstriction and the development of airway hyper reactivity following allergen broncho provocation in these animal models of asthma [25].

Crataeva tapia (Capparidaceae) is a tree broadly distributed in Brazil occurring in the Pluvial Tropical Atlantic Forest and the Pantanal. Pharmacological studies with the root bark and stem bark of Crataeva tapia, have confirmed its beneficial effects in reducing inflammatory processes [26].

Studies in the Department of Biochemistry at the Federal University of Pernambuco, with Crataeva tapia bark, identified a protein with lectin activity, Crataeva tapia Bark Lectin (Crata BL) that 
was considered a bifunctional glycoprotein, that also inhibits trypsin $(\mathrm{Kiapp}=43 \mu \mathrm{M})$ and Factor $\mathrm{Xa}(\mathrm{Kiapp}=9.2 \mu \mathrm{M})$ [27]. Crata BL contains 165 amino acid residues and shows some similarity to inhibitors of the Kunitz type family [28], such as, Bauhinia Bauhinioides Cruzipain Inhibitor (BbCI) and Bauhinia bauhinioides Kallikrein Inhibitor (BbKI).

The results obtained from inflammatory animal models pretreated with BbCI (HLE inhibitor and Cathepsin G) and BbKI (an inhibitor of human and rat plasma kallikrein) suggests the participation of these enzymes in capturing events, bearing, cellular adhesion, and transmigration and that explain the role anti-inflammatory nature of these inhibitors [29].

The proteinase-activated receptor 2 is of particular interest in asthma because it can be activated by mast cell tryptase [19] and aeroallergens [30] and has been implicated in inflammation. PAR-2 activation induces the release of GM-CSF, matrix metalloproteinase 9 and eotaxin $[31,32]$ from airway epithelial cells. Mast cells are mainly known for their harmful effects during allergic inflammation and contribute to asthma in several ways [33]. The infiltration of mast cells into the airway smooth muscle cell layer is associated with airway hyper responsiveness [34].

Efforts to understand the role of tryptase in asthma have been greatly facilitated by the identification and characterization of the tryptase- and trypsin-activated proteinase-activated receptor-2 (PAR2) [35].

The coagulation cascade is activated immediately after tissue injury; in addition to the fact that thrombin mediates fibrinogen, important effects occur through the proteolytic activity of a family of cell surface receptors, the protein activated receptors (PARs), and with regard to lung injury and inflammatory responses, most attention has focused on PAR1 and PAR2 [36].

The role of PAR2 in airway allergic inflammation was examined by comparing OVA-sensitized and -challenged mice lacking or overexpressing PAR2 with wild-type animals. Airway hyper reactivity to inhaled methacholine was reduced by $38 \%$ in the mice lacking PAR 2 and increased by $52 \%$ in the mice overexpressing PAR2. Thus, the absence of PAR2 is associated with the attenuation of ovalbuminairway hyper-responsiveness, whereas overexpression the of PAR2 results in exaggerated airway hyper-responsiveness [37].

Mice were immunized in the footpad with papain and the authors studied the leukocyte recruitment and the inflammatory cytokine and chemokine production in the draining popliteal lymph nodes. It was found that a novel innate allergen recognition pathway was mediated by naive T cells through PAR2, which provided an immediate source of chemokines and IL-4 upstream of basophils and antigen-restricted $\mathrm{T}$ helper cell (Th)-2 differentiations. These results suggest that PAR2 antagonism might be promising for the treatment of allergic disease [38].

Exogenous substances that activate PAR2 inhibited several characteristic features of allergic inflammation. The administration of a PAR2-AP, SLIGRL, inhibited the development of airway eosinophilia and hyperresponsiveness in OVA-sensitized and challenged mice through a COX-dependent pathway, possibly involving the COX-2mediated generation of prostaglandin E2 [39].

Flavonoids are polyphenolic compounds found in fruit, vegetables, and beverages such as tea and wine. Flavonoids have received much attention in the literature over the past 10 years for a variety of potential beneficial effects; anti- inflammatory, anti-allergic, antioxidant, as well as immune-modulating effects have been elucidated [40,41].

Several studies have showed the anti-inflammatory effects of flavonoids such as sakuranetine, baicalein, apigenin, luteolin, fisetin, kaempferol, quercetin and genistein by modulating pro-inflammatory cytokines, inhibiting phospholipase A2 (via the arachidonic acid pathway), lipoxygenase, cyclooxygenase and modulating iNOS thereby inhibiting NO production $[42,43]$. The exact mechanism by which flavonoids inhibit these enzymes is not clear. Furthermore, flavonoids could also suppress the expression of the COX gene through interactions with cell signaling pathways such as protein kinase C, NF-kappaB and tyrosine kinase [44,45]. In addition, flavonoids may have an additive effect on the endogenous scavenging compounds. Flavonoids could inhibit the production of reactive oxygen species by chelating transition metal ions and inhibiting the initiation of the lipoxygenase reaction [46].

Because lung diseases are characterized by chronic airway inflammation and increased oxidative stress various studies have shown the beneficial effects of flavonoids in these diseases. Sakuranetin [47] was found to reduce eosinophilic inflammation, attenuate airway hyperresponsiveness, and reverse lung remodeling in an ovalbuminimmunized asthma model in mice. These effects could be attributed to Th2 pro-inflammatory cytokines, oxidative stress reduction and the control of NF-kappaB activity. Preliminary studies also suggest that sakuranetin reduce lung emphysema as well as neutrophilic and macrophage inflammation [48], suggesting this may be a potential compound for the treatment of emphysema.

The administration of a bioflavone baicalein in mice reduced the airway hyperresponsiveness and inflammation induced by either intranasal IL-4 or IL-13 [49]. Apigenin and luteolin have been shown to decrease IL-4 and IL-5 levels in the broncho-alveolar lavage fluid (BALF) in the OVA-sensitized model [50,51]. Fisetin also showed strong inhibition of the synthesis of IL-4 and IL-13 [52] attenuating lung inflammation, goblet cell hyperplasia and airway hyperresponsiveness [53].

Kaempferol and quercetin have been shown to have a moderate inhibitory effect on IL-4 synthesis by activated basophils [52,54,55] decreasing histamine release [56] and inhibiting chemical mediator and cytokine production by mast cells [46]. Genistein may present a therapeutic potential for allergic airway inflammation, attenuating the ovalbumin-induced airway hyperresponsiveness to inhaled methacholine, pulmonary eosinophil infiltration and airway hyperresponsiveness observed in vivo models [57].

Substances derived from plants have been increasingly explored. They are used in folk medicine to treat allergic and inflammatory diseases, and the studies related above showing they can have a beneficial potencial in asthma treatment have reinforced the importance of clarifying the mechanism of action of these substances.

\section{Arginase and iNOS Inhibitors}

Nitric oxide (NO), an essential molecule in the physiology of the human body, is generated from the lysis of the guanidine molecular group of L-arginine via enzymatic oxidation [58,59] causing the release of NO and L-citrulline [60,61]. L-arginine, an NO precursor, is transported inside the cells via the cationic amino acid transport system (CAT), and it can be metabolized by two distinct groups of enzymes: the nitric oxide synthases (NOS) and arginases.

The NOS converts L-arginine into NO and L-citrulline using 
NG-hydroxyl-L-arginine as an intermediate that in its turn decreases the activity of the arginase. The L-citrulline can be converted by the argininosuccinate L-arginine, while the arginase has the ability to metabolize L-arginine into L-ornithine [62]. This process requires oxygen as a co-substrate and nicotinamide adenine dinucleotide phosphate (NADPH) as a source of electrons to convert $\mathrm{L}$-arginine to $\mathrm{L}$-citrulline and in this manner to release the nitric oxide [62].

Initial studies reporting the involvement of $\mathrm{NO}$ in bronchial asthma described the presence of high concentrations of this molecule in the exhaled breath of asthmatic patients in comparison with normal individuals $[63,64]$.

In the physiopathology of asthma its contribution to the modulation of functional and histopathological alterations depends basically on the type of enzyme responsible for its production [58]. Some authors suggest that the dysfunction of the NOS may modulate both beneficial and harmful effects $[62,65,66]$, thereby altering relevant aspects of the pathophysiology of asthma, in particular the recruitment of inflammatory cells [67-70], airways hyperresponsiveness [71], and more recently, the remodeling process $[62,72,73]$.

Therefore, by acting on the non-adrenergic non-cholinergic (NANC) nervous system, the NO derived from nNOS has beneficial effects, causing bronchodilation. However, the NO derived from the eNOS enzyme can lead to vasodilatation in the arterioles, with the consequent extravasation of plasma and edema [62].

In contrast, the increase of the concentration of $\mathrm{NO}$ formed by the inducible NO synthase (iNOS) enzyme present in several inflammatory cells results in vasodilatation, plasma extravasation, increases in mucus secretion and the indirect activation of Th2 cells, mainly by eosinophilic recruitment, thereby contributing to the aggravation of inflammation [73-75]. The hyperemia, edema and exudation, contribute to the narrowing of the airways in these patients $[62,76]$.

The iNOS expression is regulated by various mediators including tumor necrosis factor (TNF)-alpha, interferon (IFN)-gamma, interleukin (IL)-1beta, and lipopolysaccharides (LPS), and it can generate huge amounts of NO compared to with cNOS [77].

In the respiratory tract, the expression of iNOS has been demonstrated in alveolar epithelial cells [67], fibroblasts [78], smooth muscle cells of the airways and vessels [79], the epithelial cells of the airways [80,81], mast cells [82], endothelial cells [83], neutrophils [84] chondrocytes [85], eosinophils [69,70] and type II pneumocytes [77].

In asthma, iNOS has toxic and pro inflammatory effects, perpetuating and amplifying the inflammation $[62,65]$ in the airways and in the lung parenchyma. Its expression in the respiratory tract can be inhibited by the treatment with corticosteroids [86].

The cytotoxicity of NO results from its direct action, from its local concentration, from the enzyme that it was produced by and/or by its reaction with other compounds released during the inflammatory process [87].

Pharmacological strategies for inhibiting NO production had been studied in humans $[88,89]$ and in animal models of both acute $[69,90]$ and chronic inflammatory responses $[67,68]$. NO can be inhibited by the administration of an alternative substrate that inhibits the production of these enzymes or by the blockage of nitric oxide synthase enzyme [61]. Commercially we found a large number of inhibitors that are used in laboratories to block the action of these enzymes [91].
Hansel et al. [92] using L-NIL a semi selective iNOS inhibitor, in mild asthmatics and in healthy volunteers showed a potent decreased in exhaled NO in both over a period of $72 \mathrm{~h}$. On the other hand, the treatment with GW274150 (a selective iNOS inhibitor) reduced the NO levels in the asthmatics patients but had no effect on airway reactivity and inflammation [93].

Previous studies in guinea pigs with chronic allergic inflammation have shown that the chronic treatment with L-NAME increased the resistance and elastance in the airways [69] and decreased both (resistance and elastance) in the lung parenchyma [67]. These data support that $\mathrm{NO}$ acts as a bronchodilator in the proximal airways and as constrictor in the distal pulmonary parenchyma. In the airway walls, an acute treatment decreased the total number of eosinophils in the airways [69]. Alternatively, the treatment with 1400-W (an iNOS-specific inhibitor), contributed to the control of the lung hyperresponsiveness and inflammation in the airways and lung tissue in the same animal model $[68,70,74]$.

Arginases and NOS compete for the bioavailability of the same substrate, L-arginine, and are involved indirectly in the regulation of NO synthesis. Inhibitors of arginase have been used to investigate the role of arginase in the pathophysiology of asthma. According to Meurs et al. [94] the arginase pathway appears to be involved in the modulation of airway smooth muscle tone and potentiates methacholine-induced airway constriction.

Recently our group evaluated the expression and activity of arginase 2 by treatment with a specific inhibitor of arginase Nor-NOHA, in the distal parenchyma of an animal model of chronic allergic pulmonary inflammation. The authors also evaluated the iNOS expression using the $1400 \mathrm{~W}$ inhibitor. The treatment protocols were effective in reducing the arginase content and the number of iNOS-positive cells in the distal parenchyma of the animals exposed to ovalbumin and treated with nor-NOHA and $1400 \mathrm{~W}$, respectively. In this experimental model, the increased arginase content and numbers of iNOS-positive cells were associated with the constriction of the distal parenchyma [95].

In vitro studies of tracheal rings from sensitized guinea pigs have shown that the hyperresponsiveness to methacholine was reduced by treatment with nor-NOHA, and this effect was reversed by treatment with L-NAME [71].

The increase in NO can also contribute to the increase in oxidative and nitrogen reactive species. When airways cells and tissues are exposed to oxidative stress caused by contact with environmental pollutants, infections, inflammatory reactions are exacerbated. In addition, in situations in which the antioxidant systems of the body are decreased, the levels of reactive oxygen species (ROS) and reactive nitrogen species (RNS), that are responsible for several deleterious effects in the airways, and that lead to several pathological conditions, increase $[62,96]$.

After an exposure to oxidative stress, the inflammatory cells and the resident airway cells generate superoxide peroxide nitrite $\left(\mathrm{O}_{2}^{-}\right)$ through the activation of NADPH oxidase and form high amounts of nitric oxide by the increase of the expression of iNOS. In this way in the presence of oxygen free radicals, NO reacts with superoxide, leading to a higher production of peroxide nitrite ( $\left.\mathrm{ONOO}^{-}\right)$[97]. In this manner, oxidative stress is an important factor for the amplification of an inflammatory response in the airways and distal lung parenchyma in asthmatics patients [77,98].

The effects of oxidative stress pathway activation may induce 
many harmful effects on airway function, including on smooth muscle contraction [73], airway hyperresponsiveness bronchial hyper secretion the epithelial lesions and vascular exudation all of which play an important role in the pathophysiology of asthma [99].

The contact of oxidizing agents with the cell membrane causes the peroxidation of membrane lipids, which is responsible for the generation of a series of recently discovered bioactive compounds, which are analogs to the prostaglandins and are known as isoprostanes [100].

The isoprostanes have a potent biological activity and generally mediate certain aspects of oxidative injury. The route of formation of isoprostanes provides a mechanism for generating several classes of isoprostanes derived from arachidonic acid independently cyclooxygenase (COX) pathway, where F2-isoprostane isomers are distinguished because this was the first class of isoprostanes to be discovered [101].

In the lung, we can detect isoprostanes in epithelial cells, in macrophages, as well as in the smooth muscle of airways and vessels [102]. It has been suggested that the isoprostanes may act as potent smooth muscle constrictor [103]. Moreover, they are produced in the airway tissue and can contribute to the physical effects observed during the late response in asthma; the concentration of 8-epi-PGF2alpha in the exhaled breath condensate is to disease severity [104].

The evidence that asthmatic inflammation results where there is increased oxidative stress is becoming stronger [105]. Many animal model studies suggest that ROS may contribute to airway hyperresponsiveness, increased vagal tone due the sensitivity of the Beta-adrenergic receptors to oxidants and decreased mucociliary clearance.

Therefore, aspects of the antioxidant defense system as well as lipid peroxidation are often used as indirect markers of oxidative stress in asthma, because lipid peroxidation is of particular significance in this disease.

Some studies have shown high lipid peroxidation in asthma, as measured by 8-epi-PGF2alpha, and its concentration has been shown to be increased from 3-4 times in persistent asthma when compared with healthy individuals [106]. The increase in isoprostanes in the broncho alveolar lavage fluid and urine after allergen challenge is evidence that in allergen-induced asthma, ROS and lipid peroxidation have significant pathophysiological roles. Furthermore, the increase in the concentration of isoprostanes in the broncho alveolar lavage 24 hours after allergen challenge provides direct evidence that isoprostanes are produced in the airway tissue and can contribute to the physical effects observed during the late asthmatic response [101].

In addition, ROS may also induce the production of cytokines and chemokines through the activation of nuclear factor (NF)-kappa B in bronchial epithelial cells [107]. According to Tripathi and Aggarwal [108], regardless of the stimulus, oxidative stress and increased intracellular calcium appear to be involved in the activation of NFkappa B. When unstimulated, NF-kappa B remains in the cytoplasm associated with an inhibitory protein (I-kappa-B). This complex prevents the translocation of NF-kappa $B$ to the nucleus. Thus, the phosphorylation and the degradation of I-kappa $B$ are required for this translocation to occur.

Hart et al. [109] demonstrated the presence of activated NF-kappa $B$ in asthmatic airways and in inflammatory cells, suggested that NF-kappa B may have an important role in maintaining the chronic inflammatory response in asthma. In transgenic mice, Pantano et al. [110] showed that the selective activation NF-kappaB was sufficient to induce airway hyperresponsiveness and smooth muscle thickening, both critical features of allergic airway disease.

\section{Rho-Kinase Inhibitors}

The Rho/Rho-kinase pathway is associated with the regulation of multiple biological pathways, including some that influence the level of smooth muscle tone and others that affect a variety of physiological functions associated with changes in the actin cytoskeleton, such as cell adhesion, motility, migration and contractility [111]. Rho is a monomeric $\mathrm{G}$ protein belonging to the Ras superfamily of guanosine triphosphatases (GTPases).

Many effectors participate in the activation of Rho (RhoA) However, three groups of regulatory proteins are the major controllers of Rho activity: the guanine nucleotide exchange factors (GEFs), the GTPase-activating proteins (GAPs) and the GDP dissociation inhibitors (GDIs). The GEFs are considered the main regulators of Rho activity and act by facilitating Rho activation through guanosine diphosphate (GDP) dissociation and subsequent GTP-binding. The GAPs hydrolyzes GTP into GDP, while the GDIs may suppress the conversion between the Rho-GDP and Rho-GTP forms [112-114]. Once activated, the Rho protein is able to activate Rho-kinase. Rhokinase, in turn, is one of the best characterized effector molecules of the Rho protein.

The Rho-kinase is available in two isoforms: ROK (also called ROCK2) and p160 ROCK (also called ROCKbeta or ROCK1). The two isoforms have different functions, with ROCK1 acting mainly in circulating inflammatory cells and ROCK2 in vascular smooth muscle cells [115]. Regarding its distribution, ROCK1 is prominent in the lung, liver, spleen, kidney and testes, while ROCK 2 is expressed preferentially in the brain, muscles and heart [116]. It is interesting to note that, in addition to being activated by RhoA, Rho-kinase can also be activated by arachidonic acid, which is released by smooth muscle in response to various agonists $[113,114,117]$.

Therefore, because a major consequence of Rho/Rho-kinase activation is to trigger contraction, the use of inhibitors of this pathway, by promoting airway smooth muscle relaxation in the presence of elevated tone, have been predicted to be relevant to asthma $[118,119]$.

Here we summarize several mechanisms by which Rho/Rhokinase has been implicated in the pathogenesis of asthma, as well as the benefits achieved experimentally with the use of inhibitors of this pathway for the treatment of asthma.

Rho-kinase inhibitors are not investigated in humans for the treatment of asthma, but their use has greatly helped to clarify the activities and functions of this protein. Among the main pharmacological Rho-kinase inhibitors used in the context of respiratory diseases are fasudil (also known as HA-1077) and Y-27632 ([(+)-(R)-trans-4-(1aminoethyl)-N-4-pyridyl) cyclohexanecarboxamide dihydrochloride]). Fasudil is a moderate inhibitor of Rho-kinase that has been in clinical use in Japan since 1995. Fasudil inhibited ROCK by targeting the ATPdependent kinase domain and is the first and only clinically available ROCK inhibitor [120]. It was demonstrated to be effective in reversing blood vessel spasm and the constriction that may occur after episodes of subarachnoid hemorrhage [121-123].

Y-27632 is a pyridine derivative with an excellent selective inhibition of Rho-kinase when compared with other kinases, such as 
protein kinase C and myosin light-chain kinase [117,124]. Y-27632 is cell permeable and inhibits Rho-kinase by competing with the ATP binding site in this protein. Y-27632 has been shown to induce bronchodilator effects when delivered to guinea pigs as an aerosol, resulting in only minimal side effects on the systemic blood pressure [125-127]. Thus, Y-27632 is a powerful tool for investigating the role of the Rho/Rho-kinase pathway, especially in vivo; although more potent Rho-kinase inhibitors have been synthesized [124,128].

Airway hyperresponsiveness is a classic feature of asthma $[129,130]$. The increased tone of the airways is dependent on the release of neurotransmitters or mediators secreted by inflammatory cells. These agents stimulate specific G-protein receptors located on the surface of the smooth muscle cells of the airways [131]. Thereafter, in a normal smooth muscle contraction, the phosphorylation of the myosin light chain (MLC) is a key event in regulating smooth muscle contraction. In the presence of intracellular calcium, the MLC can be phosphorylated by the calcium-calmodulin-activated MLC kinase, resulting in muscle contraction through binding between actin and myosin. Subsequently, the contraction ceases due to dephosphorylation by the MLC phosphatase [132,133].

At first, it might be believed that the smooth muscle tone is proportional to the calcium concentration. However, the level of calcium does not always correspond with the degree of MLC phosphorylation and consequent smooth muscle contraction. Calcium sensitization describes the phenomenon whereby the level of calcium is insufficient to account for the degree of MLC and smooth muscle contraction $[114,134,135]$. The explanation for this is that the degree of MLC phosphorylation and therefore of smooth muscle contraction depends not only on the calcium-dependent activity of the MLC kinase but also on the activity of the myosin phosphatase that dephosphorylates the MLC [136].

Although the mechanisms responsible for the hyper responsiveness are not fully elucidated, it is believed that a major cause arises from abnormalities in the properties of the airway smooth muscle, including calcium sensitization mediated by agonists $[133,137]$. The mechanisms responsible for the calcium sensitization have not been fully elucidated, but recent studies suggest that Rho-kinase is a key protein involved in the contraction of smooth muscles [132-134]. The Rho-kinase, phosphorylates the myosin binding subunit of the MLC phosphatase, resulting in the inhibition of its activity and thus the promotion of the phosphorylated state of the MLC under low calcium conditions [133] (Figure 1).

Furthermore, Rho-kinase also seems to be involved in hyperresponsiveness by other mechanisms, including the contraction of airway smooth muscle and endothelial cells [114]; the formation of stress fibers and focal adhesions [138]; vesicular trafficking [139]; airway smooth muscle cell proliferation [126]; cell migration [140] and neurotransmitter exocytosis [118]. In this sense, several studies

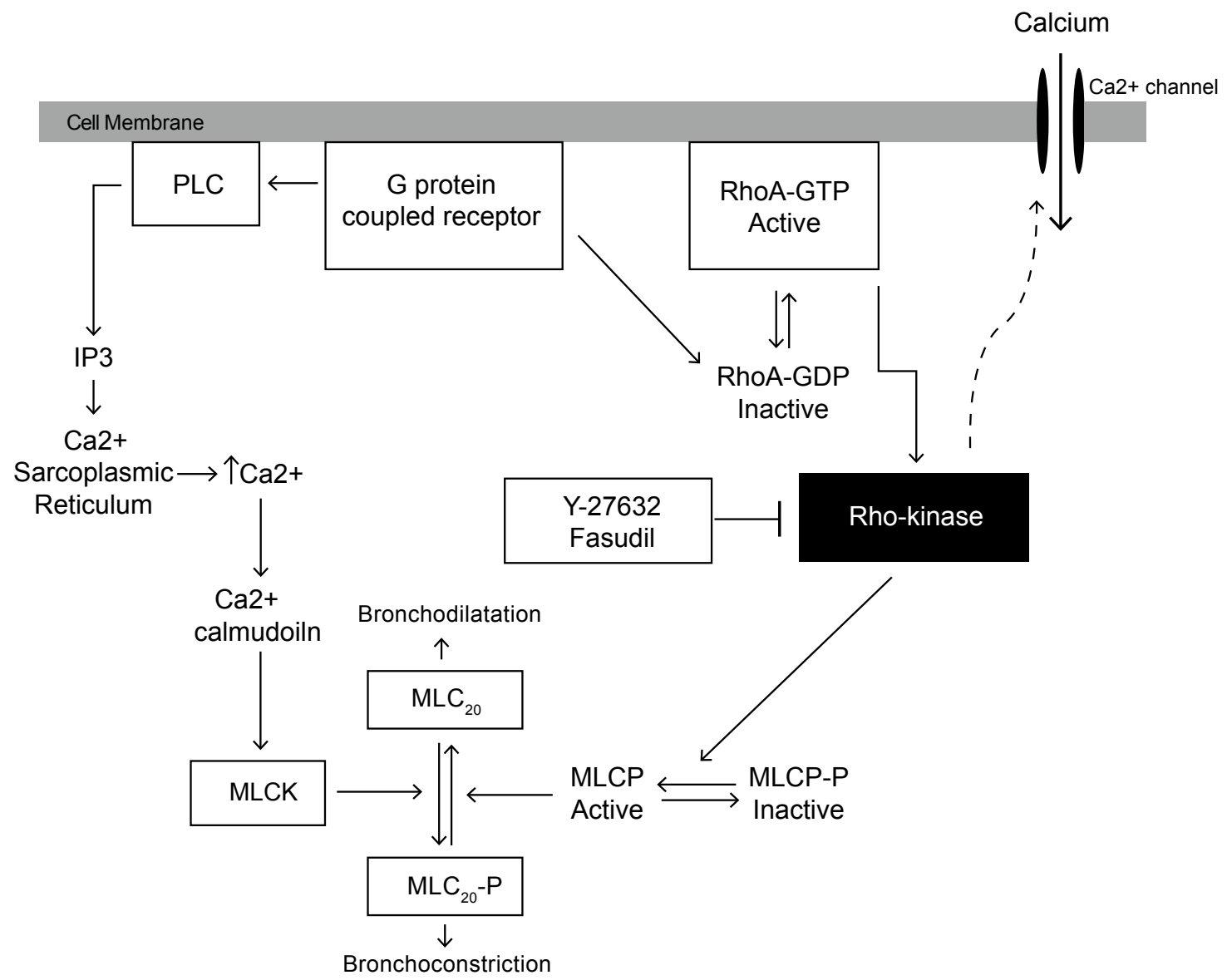

Figure 1: Diagrammatic representation of the role of the Rho/Rho-kinase pathway in airway smooth muscle contraction. Abbreviations: GTPactivating proteins; PLC, phospholipase C; DAG, diacylglycerol; MLC, myosin light chain; MLCK, myosin light chain kinase; MLCP, myosin phosphatase;Y-27632 and Fasudil, Rho-kinase inhibitors; IP3, inositol (1,4,5)-trisphosphate (Modified from Nagaoka et al., 2005). 
have reported the beneficial effects of Rho-kinase inhibition on the relaxation of airway smooth muscle both in vitro and in vivo.

The relationship between Rho-kinase and airway hyperresponsiveness has previously been demonstrated in several studies [111,119,126,132,141,142]. Schaafsma et al. [143] showed that the inhalation of Y-27632 $30 \mathrm{~min}$ before and $8 \mathrm{~h}$ after an allergen challenge in sensitized guinea pigs effectively prevented the development of airway hyperresponsiveness, after both the early and late airway reactions. Henry et al. [131] also found reduced airway resistance induced by methacholine in mice, this time with the intranasal administration of Y-27632. Possa et al. [126] demonstrated that repeated Rho-kinase inhibition with inhaled Y-27632 was associated with a reduction in the airway hyperresponsiveness in chronically sensitized guinea pigs.

Kobayashi et al. [144], in turn, using guinea pig tracheal smooth muscle preparations recently demonstrated that tryptase, which is released from mast cells in asthma, induces Beta2-adrenoceptor desensitization. In addition, the exposure to tryptase in the presence of Y-27632 prevented Beta2-adrenoceptor desensitization in the airway smooth muscle preparations. Witzenrath et al. [145] also verified that the use of Y-27632 attenuated the methacholine-provoked airway response in sensitized lungs.

The Rho-kinase pathway participates in many processes related to pulmonary inflammation, including the migration, chemotaxis and infiltration of different type of inflammatory cells into the lungs [143]. In the pathophysiology of asthma, eosinophils are associated with mucus accumulation, epithelial damage, dysfunction of airway cholinergic nerves, airway remodeling and airway hyperresponsiveness [146].

Some studies have suggested that the RhoA/Rho-kinase system plays a role in eosinophil recruitment, as well as in Th1 and Th2 cytokine secretion $[111,125,126,131]$. Aihara et al. [147] showed that Y-27632 suppressed the release of Th1 cytokines and partially suppressed the release of Th2 cytokines in healthy persons, but it reduced the release of IL- 2 and IL- 5 in asthmatic patients and weakly reduced the release of IL-4 and IFN-gamma.

Henry et al. [131] demonstrated, in a murine model of acute allergic airway inflammation, that Y-27632 inhibited the influx of eosinophils following ovalbumin challenge and that the reduction in pulmonary eosinophilia was accompanied by inhibition of the development of airways hyperresponsiveness. Additionally, Taki et al. [111] showed a reduction in the number of eosinophils in the bronchoalveolar lavage, airways and blood vessels with the use of fasudil in sensitized mice.

The Rho-kinase inhibition with Y-27632 also had shown benefits in a model of chronic allergic pulmonary inflammation in guinea pigs, in which the treatment with the inhibitor was able to reduce eosinophilic infiltration, as well as cells positive for Th1 and Th2 cytokines [126]. The same pattern of response was also found in the distal lung tissue of guinea pigs with chronic allergic pulmonary inflammation, constituting an important aspect of the treatment, because the pulmonary parenchyma has inflammatory changes and responsiveness in this disease $[95,125]$.

These data indicate that Rho-kinase inhibition has significant antiinflammatory activity in the airways and distal lung. Thus, inhibitors of Rho-kinase activity such as Y-27632 and fasudil have the potential to modulate processes in the pulmonary inflammatory response in atopic asthmatics.
The role of Rho-kinase in lung remodeling was first reported by Possa et al. [126]. Structural changes of the airway and of the lung tissue in asthmatics are key determinants of the extent of their airflow obstruction as well as lung functional alterations.

In the remodeling process, the migration of airway smooth muscle cells and fibroblasts to the airways and to distal lung tissue is the outcome of the repair process in response to persistent inflammation [148]. Cell migration has been shown to involve MLC phosphorylation, suggesting a mechanism that is possibly modulated by Rho-kinase [149]. Furthermore, the Rho/Rho kinase pathway is a key regulator of the actin cytoskeleton, directing changes in cell shape and driving the adhesion in cell migration [114]. Therefore, Rho-kinase inhibition by Y-27632 helps to prevent chronic inflammation by reducing the number of inflammatory cells and indirectly contributes to the reduction of the remodeling process, as evidenced by the lower contents of collagen and elastic fibers in the airway walls and lung tissue $[125,126]$.

It is possible that in addition to the indirect effects on fibrosis, the Rho/Rho-kinase signaling is directly involved in profibrotic processes, mediated by airway-resident cells. Schaafsma et al. [150] showed that human airway myocytes express both geranylgeranyl transferase 1 (GGT1) and farnesyl transferase (FT), and the inhibition of GGT1, but not FT, mirrored the suppressive effects of simvastatin on collagen I and fibronectin expression as well as collagen I secretion. Both simvastatin and the GGT1 inhibitor prevented the TGF-1-induced membrane association of RhoA, a downstream target of GGT1, suggesting a consequent inhibition of the synthesis and secretion of extracellular matrix proteins by human airway smooth muscle cells by suppressing the GGT1-mediated posttranslational modification of signaling molecules such as RhoA.

Kondrikov et al. [151] investigated the role of Rho-kinase and reactive oxygen species (ROS) in the synthesis of type I collagen in human and mice lung fibroblasts subjected to hyperoxia in a model of oxygen toxicity. The authors concluded that oxygen toxicity induces $\mathrm{R}$ to separate the guanine nucleotide dissociation inhibitor (a regulator of Rho GTPase activity) from Rho, which leads to the activation of the Rho-kinase pathway and contributes to increased collagen-I synthesis.

Additionally, it has already been shown that Rho-kinase inhibition reduces the number of iNOS positive cells $[126,152,153]$. In addition, it is well established that a reduction of iNOS causes the attenuation of airway constriction, inflammation and oxidative stress; it is also known that iNOS participates in extracellular matrix remodeling in asthma $[68,72]$. It has been demonstrated that the reduction in iNOS, either directly or indirectly through the inhibition of Rho-kinase, reduces the levels of MMP-9, TIMP-1 and TGF-beta both in airways and in bronchial vascular wall in ovalbumin-sensitized animals. These mediators act in the synthesis of collagen and elastic fibers, contributing to the remodeling of the extracellular matrix in the lungs and constituting a likely pathway by which Rho-kinase interferes with remodeling $[125,126]$.

\section{Cholinergic System in Inflammation}

Acetylcholine (ACh) is synthesized from choline and the cetylCoA substrate in a reaction catalyzed by the acetyltransferase enzyme (ChAT) in the cholinergic nerve terminals [154]. ACh storage in the synaptic vesicles depends on the activity of the vesicular acetylcholine transporter (VAChT) [155] which is absolutely required for ACh release in the peripheral and central nervous system [155-157], and by a large number of non-neuronal cells in various organs such as the spleen, heart and lung [158]. 
Citation: Prado CM, Righetti RF, da Silva Pigati PA, Possa SS, dos Santos ASA, et al. (2014) New Pharmacological Targets for Asthma Drug Development. J Allergy Ther 5: 170. doi:10.4172/2155-6121.1000170

Page 8 of 13

When released, ACh can interact with the muscarinic and nicotinic receptors that are expressed in the resident and in inflammatory cells in various tissues including the airways [159-162]. In the lung, ACh is known to be released from parasympathetic nerve fibers and is a wellrecognized broncho constrictor that binds to the muscarinic receptors present in the airway smooth muscle and glands [163]. For this reason, anti-muscarinic drugs are recommended for asthmatics patients mainly in an acute crisis [2].

Recently the cholinergic system has been shown to regulate the inflammatory pathway through the interaction of ACh with alpha7nAChR [164]. Studies have suggested that the interaction of ACh with the nicotinic alpha-7 receptor primarily occurs in macrophages and induces an inhibition of NF-kappa B translocation to the nucleus and consequently a reduction in the inflammatory cytokines release [161]. This mechanism is called the cholinergic anti-inflammatory pathway $[165,166]$, and it has been poorly investigated in lung diseases particularly in asthma that ACh has been considered exclusively a broncho provocative agent.

A role for the cholinergic antiinflammatory system has been described in models of acute systemic inflammation [167,168]. The cholinergic antiinflammatory system seems to depend on vagus nerve stimulation and on an additional non-neuronal cholinergic source, a population of lymphocytes in the spleen [166]. These lymphocytes release ACh that acts as an autocrine and a paracrine mediator of cytokine release from macrophages [162] (Figure 2).
This mechanism has been shown to be important for counteracting inflammation in other situations [166,169-171]. It has been suggested that the cholinergic system might participate in the pathogenesis of asthma [172]. In fact, rodents with acute lung inflammation showed reduced expression of the cholinergic markers such cholineacetyl transferase (ChAT), the high affinity choline transporter (CHT1) and the VAChT in the lung, suggesting a down-regulation of non-neuronal cholinergic activity in asthma physiopathology.

Several studies have indicated that cholinergic activity has a fundamental role in anti-inflammatory responses in different experimental models. Vagotomized mice showed an increase in inflammatory cells in the peritoneal fluid after septic peritonitis, with enhanced early and late inflammatory responses [173]. Recently, it has been suggested that the stimulation of cholinergic receptors suppresses acute lung inflammation in mice, most likely via effects on alpha7nAChR [170,171]. Hofer et al. (2008) showed that the inhibition of acetyl cholinesterase by physostigmine reduced lethality and the circulating proinflammatory cytokines TNF-alpha, IL-1beta, and IL-6 as wells as down-regulated NF-kappaB activity in a sepsis model [174].

Borovikova et al. [175] demonstrated that ACh attenuates inflammation by a direct effect on proinflammatory cytokine inhibition, instead of having an effect on anti-inflammatory cytokines.

Few studies focusing in the cholinergic anti-inflammatory system; non-neuronal sources of $\mathrm{ACh}$ and specific agonists to the nicotinic

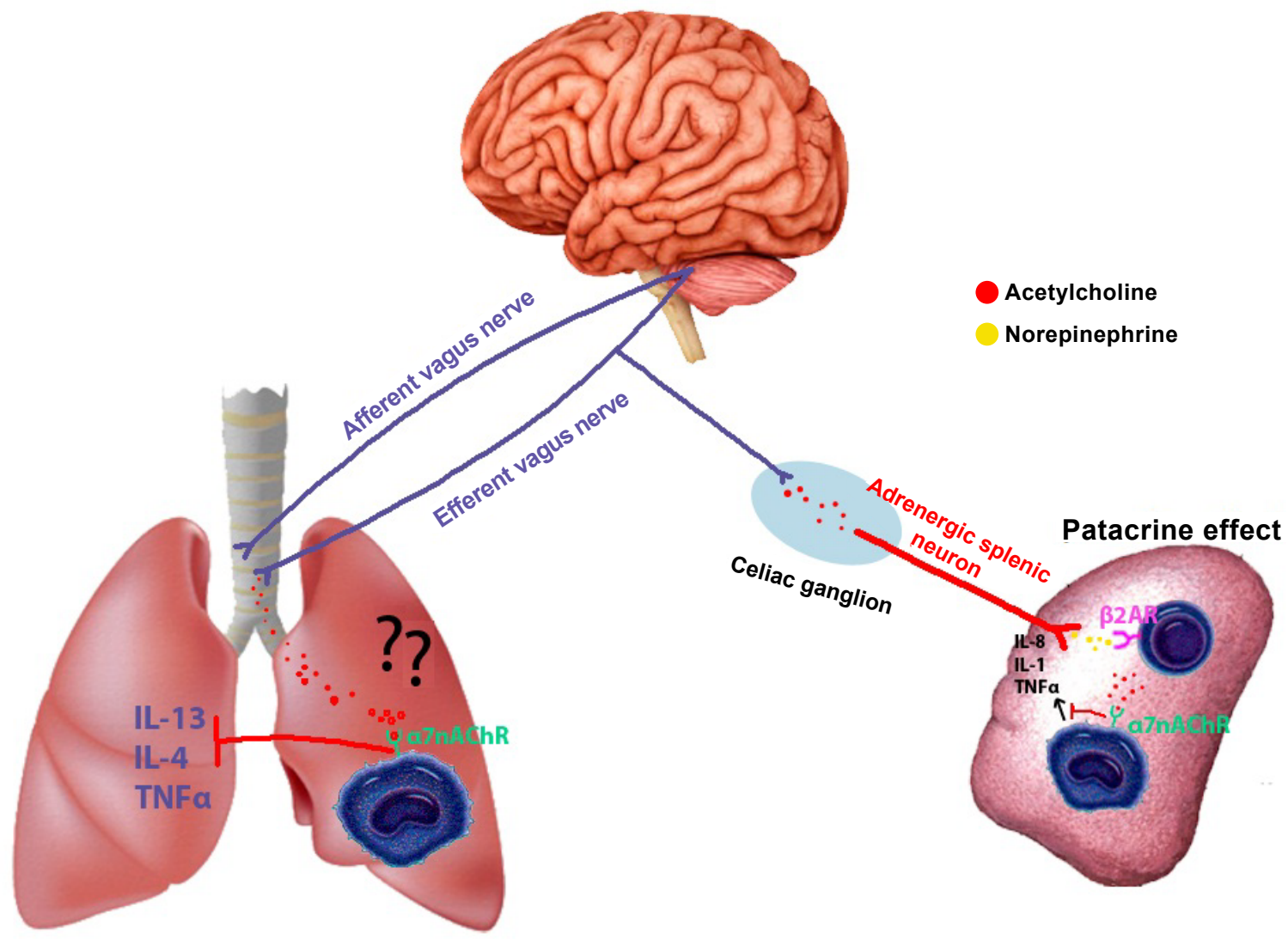

Figure 2: Hypothesis of effects of Cholinergic system in inflammation. 
receptors are used in asthma models. It was shown that anti-cholinergic therapy can amplify eosinophil interaction with airway nerves in a model of asthma in guinea pigs and can indirectly contribute to worse inflammation [176].

Our recent data (unpublished results) suggest that the reduction in VAChT, an important component directly involved in the neuronal and non-neuronal ACh release, induced worsening in eosinophilic inflammation and in collagen deposition as well as in increased Th2 cytokines and NF-kappa B.

Cytokines, particularly Th2 type cytokines, such as RANTES, eotaxin, IL-4 and IL-5 have an importance in asthma physiopathology and are increased in asthma [2]. There was evidence related to the potential therapeutic targeting of the alpha7 nicotinic acetylcholine receptor that can induce anti-inflammatory effects through the modulation of proinflammatory cytokines. However, few studies have evaluated the effects of alpha 7 agonists in asthma. Our preliminary data (unpublished results) show that treatment with PNU, an alpha7 agonist, was able to reduce eosinophilic inflammation in an asthma model.

Blanchet et al. [177] showed that the alpha-3, -4, and -7 nAChR subunits and mRNAs are expressed in humam blood eosinophils. In addition, these authors showed in vitro that treatment with nonselective nACHR nicotinic receptor agonists reduced the LTC4 production induced by platelet-activating factor (PAF) and decreased eotaxin and eosinophilic migration. These results suggest an anti-inflammatory effect obtained by nicotinic receptor stimulation which could be of interest in the treatment of allergic asthma.

The absence of acetylcholine in the alpha7 nicotinic receptors (alpha7 nAChR) should induce an increase in lung inflammation by inhibiting the cholinergic anti-inflammatory pathway and the stimulation of these receptors could have an anti-inflammatory effect, suggesting that the cholinergic anti-inflammatory system and the alpha 7 receptors could be further studied for improving the effects and the mechanisms of these new target in asthma.

\section{The importance of IL-17 in Asthma Approach}

A separate lineage of T cells called T-helper (Th)17 cells has been studied and characterized by the production of IL -17A , IL- 17F and IL- 22. In addition to the CD4+, IL- 17A and IL- 17F cytokines can be released by neutrophils, eosinophils, CD8+ T cells, basophils, and mast cells. Recent studies have provided evidence that IL -17, the main product of Th17 cells, plays an important role in regulating the expression of inflammatory mediators as well as recruitment of inflammatory cells in various inflammatory diseases. The increased expression of IL-17A has been found in asthma, suggesting involvement of this disease interleukin in the pathophysiology of the disease [178]. The IL-17 cytokine promotes airway eosinophilia by induction of chemokines and growth factors [179]. The cytokine IL-17 also appear to contribute to airway remodeling in asthma, suggesting that blocking of this pathway could help in the control of fibrosis [180]. Furthermore, especially IL-17A, but not IL-17F or IL-22 may contribute to allergic asthma by directly increasing the contractile responses of smooth muscle cells of the airways through a pathway that involves the NFkapa $\mathrm{B}$ activation and induction of expression of RhoA and ROCK2 [181]. Also, it has been found that the increase of IL-17 is associated with airway remodeling in asthma [182].

The involvement of IL-17 with other pharmacological targets approached for asthma has also been demonstrated. Flavonoids, for example, determine negative regulation of NFkapa B pathway, thus suggesting implication of IL-17 in the process [183]. Regarding iNOS, previous study highlighted the possibility of the IL-17 acting as a potent activator of inducible nitric oxide synthase, once serum IL-17 levels were positively correlated with FeNO [184]. Therefore, it can be noted that understanding the role of IL-17 is very important for the evaluation of new pharmacological targets for asthma.

\section{Conclusions}

These findings support the notion that these drugs may contribute as a treatment and/or a preventive strategy for inflammatory lung diseases because of their anti- inflammatory, antioxidant and antiallergic properties. These potential asthma therapies need to have demonstrated effectiveness against one or more features of the allergic response; the use of flavonoids, nitric oxide, arginase and Rho-kinase inhibitors as well as stimulation of the nicotinic receptors and the antiinflammatory cholinergic system seems to be promising, whether or not they are associated with corticosteroids, and may contribute to a better control of pulmonary hyperresponsiveness, inflammation and remodeling. However, these pharmacological tools need to be more intensively and clinically tested.

\section{Acknowledgements}

Laboratório de Investigação Médica do Hospital das Clínicas da Faculdade de Medicina da Universidade de São Paulo (LIM 20) for their financial support.

\section{References}

1. Kabesch M, Adcock IM (2012) Epigenetics in asthma and COPD. Biochimie 94: 2231-2241.

2. GINA report (2013) Global Strategy for Asthma Management and Prevention Global Initiative for Asthma (GINA).

3. Berger WE, Kerwin E, Bernstein DI, Pedinoff A, Bensch G, et al. (2009) Efficacy and safety evaluation of ciclesonide in subjects with mild-to-moderate asthma not currently using inhaled corticosteroids. Allergy Asthma Proc 30: 304-314.

4. Bousquet J, Wenzel S, Holgate S, Lumry W, Freeman P, et al. (2004) Predicting response to omalizumab, an anti-lgE antibody, in patients with allergic asthma. Chest 125: 1378-1386

5. Kerstjens HA, Engel M, Dahl R, Paggiaro P, Beck E, et al. (2012) Tiotropium in asthma poorly controlled with standard combination therapy. N Engl J Med 367: 1198-1207.

6. Bateman ED, Kornmann O, Schmidt P, Pivovarova A, Engel M, et al. (2011) Tiotropium is noninferior to salmeterol in maintaining improved lung function in B16-Arg/Arg patients with asthma. J Allergy Clin Immunol 128: 315-322.

7. Haselkorn T, Fish JE, Zeiger RS, Szefler SJ, Miller DP, et al. (2009) Consistently very poorly controlled asthma, as defined by the impairment domain of the Expert Panel Report 3 guidelines, increases risk for future severe asthma exacerbations in The Epidemiology and Natural History of Asthma: Outcomes and Treatment Regimens (TENOR) study. J Allergy Clin Immunol 124: 895-902.

8. Chung KF, Wenzel SE, Brozek JL, Bush A, Castro M, et al. (2014) Internationa ERS/ATS guidelines on definition, evaluation and treatment of severe asthma. Eur Respir J 43: 343-373.

9. Wenzel SE, Barnes PJ, Bleecker ER, Bousquet J, Busse W, et al. (2009) A randomized, double-blind, placebo-controlled study of tumor necrosis factoralpha blockade in severe persistent asthma. Am J Respir Crit Care Med 179 549-558.

10. Beck IM, Vanden Berghe W, Vermeulen L, Yamamoto KR, Haegeman G, et al. (2009) Crosstalk in inflammation: the interplay of glucocorticoid receptor-based mechanisms and kinases and phosphatases. Endocr Rev 30: 830-882.

11. Bel EH, Sousa A, Fleming L, Bush A, Chung KF, et al. (2011) Diagnosis and definition of severe refractory asthma: an international consensus statement from the Innovative Medicine Initiative (IMI). Thorax 66: 910-917.

12. Turk B (2006) Targeting proteases: successes, failures and future prospects. Nat Rev Drug Discov 5: 785-799. 
Citation: Prado CM, Righetti RF, da Silva Pigati PA, Possa SS, dos Santos ASA, et al. (2014) New Pharmacological Targets for Asthma Drug Development. J Allergy Ther 5: 170. doi:10.4172/2155-6121.1000170

13. de Paula CA, Coulson-Thomas VJ, Ferreira JG, Maza PK, Suzuki E, et al. (2012) Enterolobium contortisiliquum trypsin inhibitor (EcTI), a plant proteinase inhibitor, decreases in vitro cell adhesion and invasion by inhibition of Src protein-focal adhesion kinase (FAK) signaling pathways. J Biol Chem 287 170-182.

14. Puente XS, Sánchez LM, Overall CM, López-Otín C (2003) Human and mouse proteases: a comparative genomic approach. Nat Rev Genet 4: 544-558.

15. Rawlings ND, Tolle DP, Barrett AJ (2004) MEROPS: the peptidase database. Nucleic Acids Res 32: D160-164

16. Barrett AJ, Rawlings ND, Woessner JF. Jr (eds) Handbook of Proteolytic Enzymes (2nd edn) (Academic, Amsterdam, 2004)

17. Churg A, Wright JL (2005) Proteases and emphysema. Curr Opin Pulm Med 11: $153-159$

18. Berger P, Compton SJ, Molimard M, Walls AF, N'Guyen C, et al. (1999) Mast cell tryptase as a mediator of hyperresponsiveness in human isolated bronchi. Clin Exp Allergy 29: 804-812.

19. Compton SJ, Renaux B, Wijesuriya SJ, Hollenberg MD (2001) Glycosylation and the activation of proteinase-activated receptor 2 (PAR(2)) by human mast cell tryptase. Br J Pharmacol 134: 705-718.

20. Kauffman HF, van der Heide S (2003) Exposure, sensitization, and mechanisms of fungus-induced asthma. Curr Allergy Asthma Rep 3: 430-437.

21. Richardson M (1991) Seed storage proteins: the enzyme inhibitors. Meth Plant Biochem 5: 259-305.

22. Visetnan S, Donpudsa S, Supungul $P$, Tassanakajon A, Rimphanitchayakit $V$ (2009) Kazal-type serine proteinase inhibitors from the black tiger shrimp Penaeus monodon and the inhibitory activities of SPIPm4 and 5. Fish Shellfish Immunol 27: 266-274.

23. Cairns JA (2005) Inhibitors of mast cell tryptase beta as therapeutics for the treatment of asthma and inflammatory disorders. Pulm Pharmacol Ther 18 $55-66$

24. Oh KS, Mun J, Cho JE, Lee S, Yi KY, et al. (2013) Discovery of novel scaffolds for Rho kinase 2 inhibitor through TRFRET-based high throughput screening assay. Comb Chem High Throughput Screen 16: 37-46.

25. Sylvin H, Dahlbäck M, Van Der Ploeg I, Alving K (2002) The tryptase inhibitor APC-366 reduces the acute airway response to allergen in pigs sensitized to Ascaris suum. Clin Exp Allergy 32: 967-971.

26. Muhammed M, Lakshmi P (2007) A standardized natural extract offers comprehensive urinary health support and more. Phytopharmaceuticals: 3-6.

27. Araújo RM, Ferreira Rda S, Napoleão TH, Carneiro-da-Cunha Md, Coelho LC et al. (2012) Crataeva tapia bark lectin is an affinity adsorbent and insecticidal agent. Plant Sci 183: 20-26

28. Oliva ML, Ferreira Rda S, Ferreira JG, de Paula CA, Salas CE, et al. (2011) Structural and functional properties of kunitz proteinase inhibitors from leguminosae: a mini review. Curr Protein Pept Sci 12: 348-357.

29. Oliveira C, Navarro-Xavier RA, Anjos-Vallota EA, Martins JO, Silveira VL, et al. (2010) Effect of plant neutrophil elastase inhibitor on leucocyte migration, adhesion and cytokine release in inflammatory conditions. Br J Pharmacol 161 : 899-910.

30. Asokananthan N, Graham PT, Stewart DJ, Bakker AJ, Eidne KA, et al. (2002) House dust mite allergens induce proinflammatory cytokines from respiratory epithelial cells: the cysteine protease allergen, Der $p$, activates proteaseactivated receptor (PAR)-2 and inactivates PAR-1. J Immunol 169: 4572-4578.

31. Vliagoftis $H$, Schwingshackl A, Milne CD, Duszyk M, Hollenberg MD, et al (2000) Proteinase-activated receptor-2-mediated matrix metalloproteinase-9 release from airway epithelial cells. J Allergy Clin Immunol 106: 537-545.

32. Vliagoftis $H$, Schwingshackl A, Milne CD, Duszyk M, Hollenberg MD, et al (2000) Proteinase-activated receptor-2-mediated matrix metalloproteinase-9 release from airway epithelial cells. J Allergy Clin Immunol 106: 537-545.

33. Bradding P, Walls AF, Holgate ST (2006) The role of the mast cell in the pathophysiology of asthma. J Allergy Clin Immunol 117: 1277-1284.

34. Brightling CE, Bradding P, Symon FA, Holgate ST, Wardlaw AJ, et al. (2002) Mast-cell infiltration of airway smooth muscle in asthma. N Engl J Med 346 1699-1705.
35. Lan RS, Stewart GA, Henry PJ (2002) Role of protease-activated receptors in airway function: a target for therapeutic intervention? Pharmacol Ther 95 239-257.

36. Chambers RC, Scotton CJ (2012) Coagulation cascade proteinases in lung injury and fibrosis. Proc Am Thorac Soc 9: 96-101.

37. Schmidlin F, Amadesi S, Dabbagh K, Lewis DE, Knott P, et al. (2002) Proteaseactivated receptor 2 mediates eosinophil infiltration and hyperreactivity in allergic inflammation of the airway. J Immunol 169: 5315-5321.

38. Liang G, Barker T, Xie Z, Charles N, Rivera J, et al. (2012) Naive T cells sense the cysteine protease allergen papain through protease-activated receptor 2 and propel TH2 immunity. J Allergy Clin Immunol 129: 1377-1386.

39. de Campo BA, Henry PJ (2005) Stimulation of protease-activated receptor-2 inhibits airway eosinophilia, hyperresponsiveness and bronchoconstriction in a murine model of allergic inflammation. Br J Pharmacol 144: 1100-1108.

40. Magrone T, Jirillo E (2012) Influence of polyphenols on allergic immune reactions: mechanisms of action. Proc Nutr Soc 71: 316-321.

41. Kim HP, Son KH, Chang HW, Kang SS (2004) Anti-inflammatory plant flavonoids and cellular action mechanisms. J Pharmacol Sci 96: 229-245.

42. Santangelo C, Varì R, Scazzocchio B, Di Benedetto R, Filesi C, et al. (2007) Polyphenols, intracellular signalling and inflammation. Ann Ist Super Sanita 43 394-405.

43. Yoon JH, Baek SJ (2005) Molecular targets of dietary polyphenols with antiinflammatory properties. Yonsei Med J 46: 585-596.

44. Lin SY, Tsai SJ, Wang LH, Wu MF, Lee H (2002) Protection by quercetin against cooking oil fumes-induced DNA damage in human lung adenocarcinoma CL-3 cells: role of COX-2. Nutr Cancer 44: 95-101.

45. Cheong H, Ryu SY, Oak MH, Cheon SH, Yoo GS, et al. (1998) Studies of structure activity relationship of flavonoids for the anti-allergic actions. Arch Pharm Res 21: 478-480.

46. Zhu BT, Ezell EL, Liehr JG (1994) Catechol-O-methyltransferase-catalyzed rapid O-methylation of mutagenic flavonoids. Metabolic inactivation as a possible reason for their lack of carcinogenicity in vivo. J Biol Chem 269: 292299

47. Toledo AC, Sakoda CP, Perini A, Pinheiro NM, Magalhães RM, et al. (2013) Flavonone treatment reverses airway inflammation and remodelling in an asthma murine model. Br J Pharmacol 168: 1736-1749.

48. Taguchi LRT, Pinheiro NM, Olivo CR, Grecco SS, Toledo AC, et al. (2012) 5,6,7-Trihydroxy-4'-methoxy-flavanone from Baccharis Retusa (Asteraceae) attenuates elastase-induced emphysema in mice. D101 animal models of emphysema in American Thoracic Society: A6551-A6551.

49. Mabalirajan U, Ahmad T, Rehman R, Leishangthem GD, Dinda AK, et al. (2013) Baicalein reduces airway injury in allergen and IL-13 induced airway inflammation. PLoS One 8: e62916.

50. Fanelli V, Vlachou A, Ghannadian S, Simonetti U, Slutsky AS, et al. (2013) Acute respiratory distress syndrome: new definition, current and future therapeutic options. J Thorac Dis 5: 326-334.

51. Tseng TL, Chen MF, Tsai MJ, Hsu YH, Chen CP, et al. (2012) Oroxylin-A rescues LPS-induced acute lung injury via regulation of $\mathrm{NF}-\mathrm{I}^{\circ} \mathrm{B}$ signaling pathway in rodents. PLoS One 7: e47403.

52. Hirano T, Higa S, Arimitsu J, Naka T, Shima Y, et al. (2004) Flavonoids such as luteolin, fisetin and apigenin are inhibitors of interleukin-4 and interleukin-13 production by activated human basophils. Int Arch Allergy Immunol 134: 135140.

53. Wu MY, Hung SK, Fu SL (2011) Immunosuppressive effects of fisetin in ovalbumin-induced asthma through inhibition of NF-îº activity. J Agric Food Chem 59: 10496-10504.

54. Higa S, Hirano T, Kotani M, Matsumoto M, Fujita A, et al. (2003) Fisetin, a flavonol, inhibits $\mathrm{TH} 2$-type cytokine production by activated human basophils. $\mathrm{J}$ Allergy Clin Immunol 111: 1299-1306.

55. Kawai M, Hirano T, Higa S, Arimitsu J, Maruta M, et al. (2007) Flavonoids and related compounds as anti-allergic substances. Allergol Int 56: 113-123.

56. Middleton E Jr, Drzewiecki G, Krishnarao D (1981) Quercetin: an inhibitor of antigen-induced human basophil histamine release. J Immunol 127: 546-550. 
Citation: Prado CM, Righetti RF, da Silva Pigati PA, Possa SS, dos Santos ASA, et al. (2014) New Pharmacological Targets for Asthma Drug Development. J Allergy Ther 5: 170. doi:10.4172/2155-6121.1000170

57. Duan W, Kuo IC, Selvarajan S, Chua KY, Bay BH, et al. (2003) Antiinflammatory effects of genistein, a tyrosine kinase inhibitor, on a guinea pig model of asthma. Am J Respir Crit Care Med 167: 185-192.

58. Ricciardolo FL, Nijkamp FP, Folkerts G (2006) Nitric oxide synthase (NOS) as therapeutic target for asthma and chronic obstructive pulmonary disease. Curr Drug Targets 7: 721-735.

59. Ignarro LJ (2002) Nitric oxide as a unique signaling molecule in the vascular system: a historical overview. J Physiol Pharmacol 53: 503-514.

60. Culotta E, Koshland DE Jr (1992) NO news is good news. Science 258: 1862 1865.

61. Moncada S, Higgs A (1993) The L-arginine-nitric oxide pathway. N Engl J Med 329: 2002-2012.

62. Ricciardolo FL, Sterk PJ, Gaston B, Folkerts G (2004) Nitric oxide in health and disease of the respiratory system. Physiol Rev 84: 731-765.

63. Persson MG, Gustafsson LE, Wiklund NP, Moncada S, Hedqvist P (1990) Endogenous nitric oxide as a probable modulator of pulmonary circulation and hypoxic pressor response in vivo. Acta Physiol Scand 140: 449-457.

64. Alving K, Weitzberg E, Lundberg JM (1993) Increased amount of nitric oxide in exhaled air of asthmatics. Eur Respir J 6: 1368-1370.

65. Xiong Y, Karupiah G, Hogan SP, Foster PS, Ramsay AJ (1999) Inhibition of allergic airway inflammation in mice lacking nitric oxide synthase 2 . J Immuno 162: $445-452$

66. Meurs $\mathrm{H}$, Maarsingh $\mathrm{H}$, Zaagsma J (2003) Arginase and asthma: nove insights into nitric oxide homeostasis and airway hyperresponsiveness. Trends Pharmacol Sci 24: 450-455

67. Angeli P, Prado CM, Xisto DG, Silva PL, Pássaro CP, et al. (2008) Effects of chronic L-NAME treatment lung tissue responses induced by chronic pulmonary inflammation mechanics, eosinophilic and extracellular matrix. Am J Physiol Lung Cell Mol Physiol 294: L1197-L1205.

68. Starling CM, Prado CM, Leick-Maldonado EA, Lanças T, Reis FG, et al. (2009) Inducible nitric oxide synthase inhibition attenuates lung tissue responsiveness and remodeling in a model of chronic pulmonary inflammation in guinea pigs. Respir Physiol Neurobiol 165: 185-194.

69. Prado CM, Leick-Maldonado EA, Kasahara DI, Capelozzi VL, Martins MA, et al. (2005) Effects of acute and chronic nitric oxide inhibition in an experimental model of chronic pulmonary allergic inflammation in guinea pigs. Am J Physio Lung Cell Mol Physiol 289: L677-683.

70. Prado CM, Leick-Maldonado EA, Arata V, Kasahara DI, Martins MA, et al (2005) Neurokinins and inflammatory cell iNOS expression in guinea pigs with chronic allergic airway inflammation. Am J Physiol Lung Cell Mol Physiol 288 L741-748.

71. Meurs H, McKay S, Maarsingh H, Hamer MA, Macic L, et al. (2002) Increased arginase activity underlies allergen-induced deficiency of cNOS-derived nitric oxide and airway hyperresponsiveness. Br J Pharmacol 136: 391-398.

72. Prado CM, Leick-Maldonado EA, Yano L, Leme AS, Capelozzi VL, et al. (2006) Effects of nitric oxide synthases in chronic allergic airway inflammation and remodeling. Am J Respir Cell Mol Biol 35: 457-465.

73. Prado CM, Yano L, Rocha G, Starling CM, Capelozzi VL, et al. (2011) Effects of inducible nitric oxide synthase inhibition in bronchial vascular remodelinginduced by chronic allergic pulmonary inflammation. Exp Lung Res 37: 259268

74. Souza FC, Gobbato NB, Maciel RG, Prado CM, Martins MA, et al. (2013) Effects of corticosteroid, montelukast and iNOS inhibition on distal lung with chronic inflammation. Respir Physiol Neurobiol 185: 435-445.

75. Reis FG, Marques RH, Starling CM, Almeida-Reis R, Vieira RP, et al. (2012) Stress amplifies lung tissue mechanics, inflammation and oxidative stress induced by chronic inflammation. Exp Lung Res 38: 344-354.

76. Marques RH, Reis FG, Starling CM, Cabido C, de Almeida-Reis R, et al (2012) Inducible nitric oxide synthase inhibition attenuates physical stressinduced lung hyper-responsiveness and oxidative stress in animals with lung inflammation. Neuroimmunomodulation 19: 158-170.

77. Sugiura H, Ichinose M (2011) Nitrative stress in inflammatory lung diseases Nitric Oxide 25: 138-144.

78. Romanska HM, Polak JM, Coleman RA, James RS, Harmer DW, et al. (2002)
iNOS gene upregulation is associated with the early proliferative response of human lung fibroblasts to cytokine stimulation. J Pathol 197: 372-379.

79. Thomae KR, Geller DA, Billiar TR, Davies P, Pitt BR, et al. (1993) Antisense oligodeoxynucleotide to inducible nitric oxide synthase inhibits nitric oxide synthesis in rat pulmonary artery smooth muscle cells in culture. Surgery 114 272-277.

80. Watkins DN, Peroni DJ, Basclain KA, Garlepp MJ, Thompson PJ (1997) Expression and activity of nitric oxide synthases in human airway epithelium. Am J Respir Cell Mol Biol 16: 629-639.

81. Pechkovsky DV, Zissel G, Stamme C, Goldmann T, Ari Jaffe H, et al. (2002) Human alveolar epithelial cells induce nitric oxide synthase-2 expression in alveolar macrophages. Eur Respir J 19: 672-683.

82. Gilchrist M, Savoie M, Nohara O, Wills FL, Wallace JL, et al. (2002) Nitric oxide synthase and nitric oxide production in vivo-derived mast cells. J Leukoc Biol 71: $618-624$.

83. Ermert M, Ruppert C, Günther A, Duncker HR, Seeger W, et al. (2002) Cellspecific nitric oxide synthase-isoenzyme expression and regulation in response to endotoxin in intact rat lungs. Lab Invest 82: 425-441.

84. Blackford JA Jr, Antonini JM, Castranova V, Dey RD (1994) Intratrachea instillation of silica up-regulates inducible nitric oxide synthase gene expression and increases nitric oxide production in alveolar macrophages and neutrophils. Am J Respir Cell Mol Biol 11: 426-431.

85. Kobzik L, Bredt DS, Lowenstein CJ, Drazen J, Gaston B, et al. (1993) Nitric oxide synthase in human and rat lung: immunocytochemical and histochemical localization. Am J Respir Cell Mol Biol 9: 371-377.

86. Haddad EB, Liu SF, Salmon M, Robichaud A, Barnes PJ, et al. (1995) Expression of inducible nitric oxide synthase mRNA in Brown Norway rats exposed to ozone: effect of dexamethasone. Eur J Pharmacol 293: 287-290.

87. Schuiling M, Meurs H, Zuidhof AB, Venema N, Zaagsma J (1998) Dual action of iNOS-derived nitric oxide in allergen-induced airway hyperreactivity in conscious, unrestrained guinea pigs. Am J Respir Crit Care Med 158: 1442 1449.

88. Gómez FP, Martínez Pallí G, Barberà JA, Roca J, Rodríguez-Roisin R (1998) [Measurement of exhaled nitric oxide in healthy subjects]. Med Clin (Barc) 111 $1-5$

89. Brindicci C, Ito K, Barnes PJ, Kharitonov SA (2007) Effect of an inducible nitric oxide synthase inhibitor on differential flow-exhaled nitric oxide in asthmatic patients and healthy volunteers. Chest 132: 581-588.

90. Persson MG, Friberg SG, Hedqvist P, Gustafsson LE (1993) Endogenous nitric oxide counteracts antigen-induced bronchoconstriction. Eur J Pharmacol 249 R7-8.

91. Prado CM, Martins MA, Tibério IF (2011) Nitric oxide in asthma physiopathology. ISRN Allergy 2011: 832560

92. Hansel TT, Kharitonov SA, Donnelly LE, Erin EM, Currie MG, et al. (2003) A selective inhibitor of inducible nitric oxide synthase inhibits exhaled breath nitric oxide in healthy volunteers and asthmatics. FASEB J 17: 1298-1300.

93. Singh D, Richards D, Knowles RG, Schwartz S, Woodcock A, et al. (2007) Selective inducible nitric oxide synthase inhibition has no effect on allergen challenge in asthma. Am J Respir Crit Care Med 176: 988-993.

94. Meurs H, Hamer MA, Pethe S, Vadon-Le Goff S, Boucher JL, et al. (2000) Modulation of cholinergic airway reactivity and nitric oxide production by endogenous arginase activity. Br J Pharmacol 130: 1793-1798.

95. Aristoteles LR, Righetti RF, Pinheiro NM, Franco RB, Starling CM, et al. (2013) Modulation of the oscillatory mechanics of lung tissue and the oxidative stress response induced by arginase inhibition in a chronic allergic inflammation model. BMC Pulm Med 15: 13-52.

96. Wood LG, Gibson PG, Garg ML (2003) Biomarkers of lipid peroxidation, airway inflammation and asthma. Eur Respir J 21: 177-186.

97. Pryor WA, Squadrito GL (1995) The chemistry of peroxynitrite: a product from the reaction of nitric oxide with superoxide. Am J Physiol 268: L699-722.

98. Shiraki A, Kume H, Oguma T, Makino Y, Ito S, et al. (2009) Role of Ca2+ mobilization and $\mathrm{Ca} 2+$ sensitization in 8-iso-PGF 2 alpha-induced contraction in airway smooth muscle. Clin Exp Allergy 39: 236-245. 
Citation: Prado CM, Righetti RF, da Silva Pigati PA, Possa SS, dos Santos ASA, et al. (2014) New Pharmacological Targets for Asthma Drug Development. J Allergy Ther 5: 170. doi:10.4172/2155-6121.1000170

99. Holguin F (2013) Oxidative stress in airway diseases. Ann Am Thorac Soc 10: S150-157.

100. Morrow JD (2006) The isoprostanes - unique products of arachidonate peroxidation: their role as mediators of oxidant stress. Curr Pharm Des 12 895-902.

101. Milne GL, Yin H, Morrow JD (2008) Human biochemistry of the isoprostane pathway. J Biol Chem 283: 15533-15537.

102. Talati M, Meyrick B, Peebles RS Jr, Davies SS, Dworski R, et al. (2006) Oxidant stress modulates murine allergic airway responses. Free Radic Bio Med 40: 1210-1219.

103. Kawikova I, Barnes PJ, Takahashi T, Tadjkarimi S, Yacoub MH, et al. (1996) 8-Epi-PGF2 alpha, a novel noncyclooxygenase-derived prostaglandin, constricts airways in vitro. Am J Respir Crit Care Med 153: 590-596.

104. Montuschi P, Corradi M, Ciabattoni G, Nightingale J, Kharitonov SA, et al. (1999) Increased 8-isoprostane, a marker of oxidative stress, in exhaled condensate of asthma patients. Am J Respir Crit Care Med 160: 216-220.

105. Dworski R (2000) Oxidant stress in asthma. Thorax 55: S51-53.

106. Wood LG, Fitzgerald DA, Gibson PG, Cooper DM, Garg ML (2000) Lipid peroxidation as determined by plasma isoprostanes is related to disease severity in mild asthma. Lipids 35: 967-974.

107. Biagioli MC, Kaul P, Singh I, Turner RB (1999) The role of oxidative stress in rhinovirus induced elaboration of IL-8 by respiratory epithelial cells. Free Radic Biol Med 26: 454-462.

108. Tripathi $P$, Aggarwal A (2006). NF-kB transcription factor: a key player in the genera-tion of immune response. Curr Sci. 90: 519-531.

109. Hart LA, Krishnan VL, Adcock IM, Barnes PJ, Chung KF (1998) Activation and localization of transcription factor, nuclear factor-kappaB, in asthma. Am J Respir Crit Care Med 158: 1585-1592.

110. Pantano C, Ather JL, Alcorn JF, Poynter ME, Brown AL, et al. (2008) Nuclear factor-kappaB activation in airway epithelium induces inflammation and hyperresponsiveness. Am J Respir Crit Care Med 177: 959-969.

111. Taki F, Kume H, Kobayashi T, Ohta H, Aratake H, et al. (2007) Effects of Rhokinase inactivation on eosinophilia and hyper-reactivity in murine airways by allergen challenges. Clin Exp Allergy 37: 599-607.

112. Schaafsma D, Gosens R, Zaagsma J, Halayko AJ, Meurs H (2008) Rho kinase inhibitors: a novel therapeutical intervention in asthma? Eur J Pharmacol 585: 398-406.

113. Wettschureck N, Offermanns S (2002) Rho/Rho-kinase mediated signaling in physiology and pathophysiology. J Mol Med (Berl) 80: 629-638.

114. Fukata Y, Amano M, Kaibuchi K (2001) Rho-Rho-kinase pathway in smooth muscle contraction and cytoskeletal reorganization of non-muscle cells. Trends Pharmacol Sci 22: 32-39.

115. Satoh K, Fukumoto Y, Shimokawa H (2011) Rho-kinase: important new therapeutic target in cardiovascular diseases. Am J Physiol Heart Circ Physio 301: H287-296.

116. Shahin R, Alqtaishat S, Taha MO (2012) Elaborate ligand-based modeling reveal new submicromolar Rho kinase inhibitors. J Comput Aided Mol Des 26: 249-266.

117. Feng J, Ito M, Kureishi Y, Ichikawa K, Amano M, et al. (1999) Rho-associated kinase of chicken gizzard smooth muscle. J Biol Chem 274: 3744-3752.

118. Doussau F, Gasman S, Humeau Y, Vitiello F, Popoff M, et al. (2000) A Rhorelated GTPase is involved in $\mathrm{Ca}(2+)$-dependent neurotransmitter exocytosis. J Biol Chem 275: 7764-7770.

119. Gosens R, Schaafsma D, Grootte Bromhaar MM, Vrugt B, Zaagsma J, et al. (2004) Growth factor-induced contraction of human bronchial smooth muscle is Rho-kinase-dependent. Eur J Pharmacol 494: 73-76.

120.Bain J, Plater L, Elliott M, Shpiro N, Hastie CJ, et al. (2007) The selectivity of protein kinase inhibitors: a further update. Biochem J 408: 297-315.

121. Hirooka $Y$, Shimokawa $\mathrm{H}$ (2005) Therapeutic potential of rho-kinase inhibitors in cardiovascular diseases. Am J Cardiovasc Drugs 5: 31-39.

122. Zhao J, Zhou D, Guo J, Ren Z, Zhou L, et al. (2006) Effect of fasudi hydrochloride, a protein kinase inhibitor, on cerebral vasospasm and delayed cerebral ischemic symptoms after aneurysmal subarachnoid hemorrhage. Neurol Med Chir (Tokyo) 46: 421-428.

123. Mong PY, Wang Q (2009) Activation of Rho kinase isoforms in lung endothelial cells during inflammation. J Immunol 182: 2385-2394.

124. Uehata M, Ishizaki T, Satoh H, Ono T, Kawahara T, et al. (1997) Calcium sensitization of smooth muscle mediated by a Rho-associated protein kinase in hypertension. Nature 389: 990-994.

125. Righetti RF, Pigati PA2, Possa SS3, Habrum FC4, Xisto DG5, et al. (2014) Effects of Rho-kinase inhibition in lung tissue with chronic inflammation. Respir Physiol Neurobiol 192: 134-146.

126. Possa SS, Charafeddine HT, Righetti RF, da Silva PA, Almeida-Reis R, et al. (2012) Rho-kinase inhibition attenuates airway responsiveness, inflammation, matrix remodeling, and oxidative stress activation induced by chronic inflammation. Am J Physiol Lung Cell Mol Physiol 303: L939-L952.

127. lizuka K, Shimizu Y, Tsukagoshi H, Yoshii A, Harada T, et al. (2000) Evaluation of $\mathrm{Y}-27632$, a rho-kinase inhibitor, as a bronchodilator in guinea pigs. Eur $J$ Pharmacol 406: 273-279.

128. Tanaka H, Ohsima N, Takagi M, Komeima K, Hidaka H (1998) Nove vascular relaxant, HMN-1152: its molecular mechanism of action. NaunynSchmiedeberg's. Arch Pharmacol 385: R219.

129. Cockcroft DW, Davis BE (2006) Mechanisms of airway hyperresponsiveness. J Allergy Clin Immunol 118: 551-559.

130. Busse WW (2010) The relationship of airway hyperresponsiveness and airway inflammation: Airway hyperresponsiveness in asthma: its measurement and clinical significance. Chest 138: 4S-10S.

131. Henry PJ, Mann TS, Goldie RG (2005) A rho kinase inhibitor, Y-27632 inhibits pulmonary eosinophilia, bronchoconstriction and airways hyperresponsiveness in allergic mice. Pulm Pharmacol Ther 18: 67-74.

132. Schaafsma D, Bos IS, Zuidhof AB, Zaagsma J, Meurs H (2006) Inhalation of the Rho-kinase inhibitor Y-27632 reverses allergen-induced airway hyperresponsiveness after the early and late asthmatic reaction. Respir Res 7: 121.

133. Chiba $\mathrm{Y}$, Matsusue $\mathrm{K}$, Misawa M (2010) RhoA, a possible target for treatment of airway hyperresponsiveness in bronchial asthma. J Pharmacol Sci 114: 239-247.

134. Hashimoto T, Nakano Y, Yamashita M, Fang YI, Ohata H, et al. (2002) Role of Rho-associated protein kinase and histamine in lysophosphatidic acid-induced airway hyperresponsiveness in guinea pigs. Jpn J Pharmacol 88: 256-261.

135. Sylvester JT (2004) The tone of pulmonary smooth muscle: ROK and Rho music? Am J Physiol Lung Cell Mol Physiol 287: L624-630.

136. Burdyga T, Mitchell RW, Ragozzino J, Ford LE (2003) Force and myosin ligh chain phosphorylation in dog airway smooth muscle activated in different ways. Respir Physiol Neurobiol 137: 141-149.

137. Martin JG, Duguet A, Eidelman DH (2000) The contribution of airway smooth muscle to airway narrowing and airway hyperresponsiveness in disease. Eur Respir J 16: 349-354.

138. Katoh K, Kano Y, Amano M, Kaibuchi K, Fujiwara K (2001) Stress fiber organization regulated by MLCK and Rho-kinase in cultured human fibroblasts. Am J Physiol Cell Physiol 280: C1669-1679.

139. Symons M, Rusk N (2003) Control of vesicular trafficking by Rho GTPases Curr Biol 13: R409-418.

140.Parameswaran K, Cox G, Radford K, Janssen LJ, Sehmi R, et al. (2002 Cysteinyl leukotrienes promote human airway smooth muscle migration. Am J Respir Crit Care Med 166: 738-742.

141. Hashimoto K, Peebles RS Jr, Sheller JR, Jarzecka K, Furlong J, et al (2002) Suppression of airway hyperresponsiveness induced by ovalbumin sensitisation and RSV infection with Y-27632, a Rho kinase inhibitor. Thorax 57: 524-527.

142. Girodet PO, Ozier A, Bara I, Tunon de Lara JM, Marthan R, et al. (2011) Airway remodeling in asthma: new mechanisms and potential for pharmacological intervention. Pharmacol Ther 130: 325-337.

143. Schaafsma D, Bos IS, Zuidhof AB, Zaagsma J, Meurs H (2008) The inhaled Rho kinase inhibitor $\mathrm{Y}-27632$ protects against allergen-induced acute 
Citation: Prado CM, Righetti RF, da Silva Pigati PA, Possa SS, dos Santos ASA, et al. (2014) New Pharmacological Targets for Asthma Drug Development. J Allergy Ther 5: 170. doi:10.4172/2155-6121.1000170

bronchoconstriction, airway hyperresponsiveness, and inflammation. Am J Physiol Lung Cell Mol Physiol 295: L214-219.

144. Kobayashi M, Kume H, Oguma T, Makino Y, Ito Y, et al. (2008) Mast cel tryptase causes homologous desensitization of beta-adrenoceptors by $\mathrm{Ca} 2+$ sensitization in tracheal smooth muscle. Clin Exp Allergy 38: 135-144.

145. Witzenrath M, Ahrens B, Schmeck B, Kube SM, Hippenstiel S, et al. (2008) Rho-kinase and contractile apparatus proteins in murine airway hyperresponsiveness. Exp Toxicol Pathol 60: 9-15.

146. Kay AB (2005) The role of eosinophils in the pathogenesis of asthma. Trends Mol Med 11: 148-152.

147. Aihara M, Dobashi K, lizuka K, Nakazawa T, Mori M (2004) Effect of Y-27632 on release of cytokines from peripheral $T$ cells in asthmatic patients and normal subjects. Int Immunopharmacol 4: 557-561.

148. Holgate ST (2008) Pathogenesis of asthma. Clin Exp Allergy 38: 872-897.

149. Nishiguchi F, Fukui R, Hoshiga M, Negoro N, li M, et al. (2003) Different migratory and proliferative properties of smooth muscle cells of coronary and femoral artery. Atherosclerosis 171: 39-47.

150. Schaafsma D, Dueck G, Ghavami S, Kroeker A, Mutawe MM, et al. (2011) The mevalonate cascade as a target to suppress extracellular matrix synthesis by human airway smooth muscle. Am J Respir Cell Mol Biol 44: 394-403.

151. Kondrikov D, Caldwell RB, Dong Z, Su Y (2011) Reactive oxygen speciesdependent RhoA activation mediates collagen synthesis in hyperoxic lung fibrosis. Free Radic Biol Med 50: 1689-1698.

152. Soliman H, Craig GP, Nagareddy P, Yuen VG, Lin G, et al. (2008) Role of inducible nitric oxide synthase in induction of RhoA expression in hearts from diabetic rats. Cardiovasc Res 79: 322-330.

153. McGown CC, Brown NJ, Hellewell PG, Brookes ZL (2011) ROCK induced inflammation of the microcirculation during endotoxemia mediated by nitric oxide synthase. Microvasc Res 81: 281-288.

154.Prado MA, Reis RA, Prado VF, de Mello MC, Gomez MV, et al. (2002) Regulation of acetylcholine synthesis and storage. Neurochem Int 41: 291 299.

155. de Castro BM, De Jaeger X, Martins-Silva C, Lima RD, Amaral E, et al. (2009) The vesicular acetylcholine transporter is required for neuromuscular development and function. Mol Cell Biol 29: 5238-5250.

156. Prado VF, Martins-Silva C, de Castro BM, Lima RF, Barros DM, et al. (2006b) The Vesicular Acetylcholine Transporter is Required for Neuromuscular Development and Function. Mol and Cel Biol 29: 5238-5250.

157. Guzman MS, De Jaeger X, Raulic S, Souza IA, Li AX, et al. (2011). Elimination of the vesicular acetylcholine transporter in the striatum reveals regulation of behaviour by cholinergic-glutamatergic co-transmission. PLoS Biol 9: e 1001194.

158. Weibel ER (1963) Principles and methods for the morphometric study of the lung and other organs. Lab Invest 12: 131-155.

159. Gwilt CR, Donnelly LE, Rogers DF (2007) The non-neuronal cholinergic system in the airways: an unappreciated regulatory role in pulmonary inflammation? Pharmacol Ther 115: 208-222.

160. Kummer W, Lips KS, Pfeil U (2008) The epithelial cholinergic system of the airways. Histochem Cell Biol 130: 219-234.

161.Tracey KJ (2007) Physiology and immunology of the cholinergic antiinflammatory pathway. J Clin Invest 117: 289-296.

162. Pavlov VA, Tracey KJ (2006) Controlling inflammation: the cholinergic antiinflammatory pathway. Biochem Soc Trans 34: 1037-1040.

163. Ishii M, Kurachi Y (2006) Muscarinic acetylcholine receptors. Curr Pharm Des 12: 3573-3581.

164. Gallowitsch-Puerta M, Tracey KJ (2005) Immunologic role of the cholinergic anti-inflammatory pathway and the nicotinic acetylcholine alpha 7 receptor. Ann N Y Acad Sci 1062: 209-219.

165. Borovikova LV, Ivanova S, Zhang M, Yang H, Botchkina Gl, et al. (2000) Vagus nerve stimulation attenuates the systemic inflammatory response to endotoxin. Nature 405: 458-462.

166. Rosas-Ballina M, Olofsson PS, Ochani M, Valdés-Ferrer SI, Levine YA, et al.
(2011) Acetylcholine-synthesizing T cells relay neural signals in a vagus nerve circuit. Science 334: 98-101.

167. van Westerloo DJ, Giebelen IA, Florquin S, Daalhuisen J, Bruno MJ, et al. (2004) Cholinergic agonists inhibit HMGB1 release and improve survival in experimental sepsis. Nat Med 10: 1216-1221.

168. Song XM, Li JG, Wang YL, Hu ZF, Zhou Q, et al. (2008) The protective effect of the cholinergic anti-inflammatory pathway against septic shock in rats. Shock 30: 468-472.

169. Wang H, Yu M, Ochani M, Amella CA, Tanovic M, et al. (2003) Nicotinic acetylcholine receptor alpha7 subunit is an essential regulator of inflammation. Nature 421: 384-388.

170. Su X, Lee JW, Matthay ZA, Mednick G, Uchida T, et al. (2007) Activation of the alpha7 $\mathrm{nAChR}$ reduces acid-induced acute lung injury in mice and rats. Am J Respir Cell Mol Biol 37: 186-192.

171.Su X, Matthay MA, Malik AB (2010) Requisite role of the cholinergic alpha7 nicotinic acetylcholine receptor pathway in suppressing Gram-negative sepsis-induced acute lung inflammatory injury. J Immunol 184: 401-410.

172.Lips KS, Lührmann A, Tschernig T, Stoeger T, Alessandrini F, et al. (2007) Down-regulation of the non-neuronal acetylcholine synthesis and release machinery in acute allergic airway inflammation of rat and mouse. Life Sci 80: 2263-2269.

173. van Westerloo DJ, Giebelen IA, Florquin S, Daalhuisen J, Bruno MJ, et al. (2005) The cholinergic anti-inflammatory pathway regulates the host response during septic peritonitis. J Infect Dis 191: 2138-2148.

174. Hofer S, Eisenbach C, Lukic IK, Schneider L, Bode K, et al. (2008) Pharmacologic cholinesterase inhibition improves survival in experimental sepsis. Crit Care Med 36: 404-408.

175. Borovikova LV, Ivanova S, Zhang M, Yang H, Botchkina Gl, et al. (2000) Vagus nerve stimulation attenuates the systemic inflammatory response to endotoxin. Nature 405: 458-462.

176. Verbout NG, Jacoby DB, Gleich GJ, Fryer AD (2009) Atropine-enhanced antigen challenge-induced airway hyperreactivity in guinea pigs is mediated by eosinophils and nerve growth factor. Am J Physiol Lung Cell Mol Physio 297: L228-237.

177. Blanchet MR, Langlois A, Israël-Assayag E, Beaulieu MJ, Ferland C, et al. (2007) Modulation of eosinophil activation in vitro by a nicotinic receptor agonist. J Leukoc Biol 81: 1245-1251.

178. Park SJ, Lee YC (2010) Interleukin-17 regulation: an attractive therapeutic approach for asthma. Respir Res 11: 78.

179. Alcorn JF, Crowe CR, Kolls JK (2010) TH17 cells in asthma and COPD. Annu Rev Physiol 72: 495-516.

180.Al-Muhsen S, Letuve S, Vazquez-Tello A, Pureza MA, Al-Jahdali H, et al (2013) Th17 cytokines induce pro-fibrotic cytokines release from human eosinophils. Respir Res 14: 34.

181. Kudo M, Melton AC, Chen C, Engler MB, Huang KE, et al. (2012) IL-17A produced by $\hat{I} \pm \hat{l}^{2} T$ cells drives airway hyper-responsiveness in mice and enhances mouse and human airway smooth muscle contraction. Nat Med 18: 547-554.

182.Zhao J, Lloyd CM, Noble A (2013) Th17 responses in chronic allergic airway inflammation abrogate regulatory T-cell-mediated tolerance and contribute to airway remodeling. Mucosal Immunol 6: 335-346.

183. Goh FY, Upton N, Guan S, Cheng C, Shanmugam MK, et al. (2012) Fisetin, a bioactive flavonol, attenuates allergic airway inflammation through negative regulation of NF-Î̊B. Eur J Pharmacol 679: 109-116.

184. Chien JW, Lin CY, Yang KD, Lin CH, Kao JK, et al. (2013) Increased IL17A secreting CD4+ T cells, serum IL-17 levels and exhaled nitric oxide are correlated with childhood asthma severity. Clin Exp Allergy 43: 1018-1026. 